\title{
Begravede dale i Jylland og på Fyn - nu pa internettet!
}

Af geolog Peter Sandersen, Watertech og geolog Flemming Jørgensen, Vejle Amt

De jysk-fynske amters Grundvandssamarbejde har igennem de seneste 6 år udført en kortlægning af begravede dale i Jylland og på Fyn.

Grundvandssamarbejdet giver mulighed for at få gennemført mere regionalt dækkende projekter på tværs af amtsgrænserne, og de begravede dalsystemer respekterer jo netop ikke amtsgrænser!

Begravede dale er gamle dalstrukturer dannet af istidernes gletschere og smeltevand og fyldt helt eller delvist op med lerede og sandede aflejringer. Dalene er vigtige, fordi de ofte indeholder betydelige sand- og gruslag, som enten udgør grundvandsmagasiner eller kan fungere som forureningsveje ned til dybereliggende magasiner. Dalene udgør altså på én og samme tid både muligheder for og trusler imod vandforsyningen. En stor del af den danske vandforsyning er baseret på indvinding fra grundvandsmagasiner $\mathrm{i}$ begravede dale.

Større antal dale end tidligere antaget At der eksisterer dale i den danske undergrund har været velkendt i mange år, men antallet af dale har i de senere år vist sig at være væsentligt større end tidligere antaget. Amternes kortlægningsprojekt har på grund af det meget store antal fundne dale øget

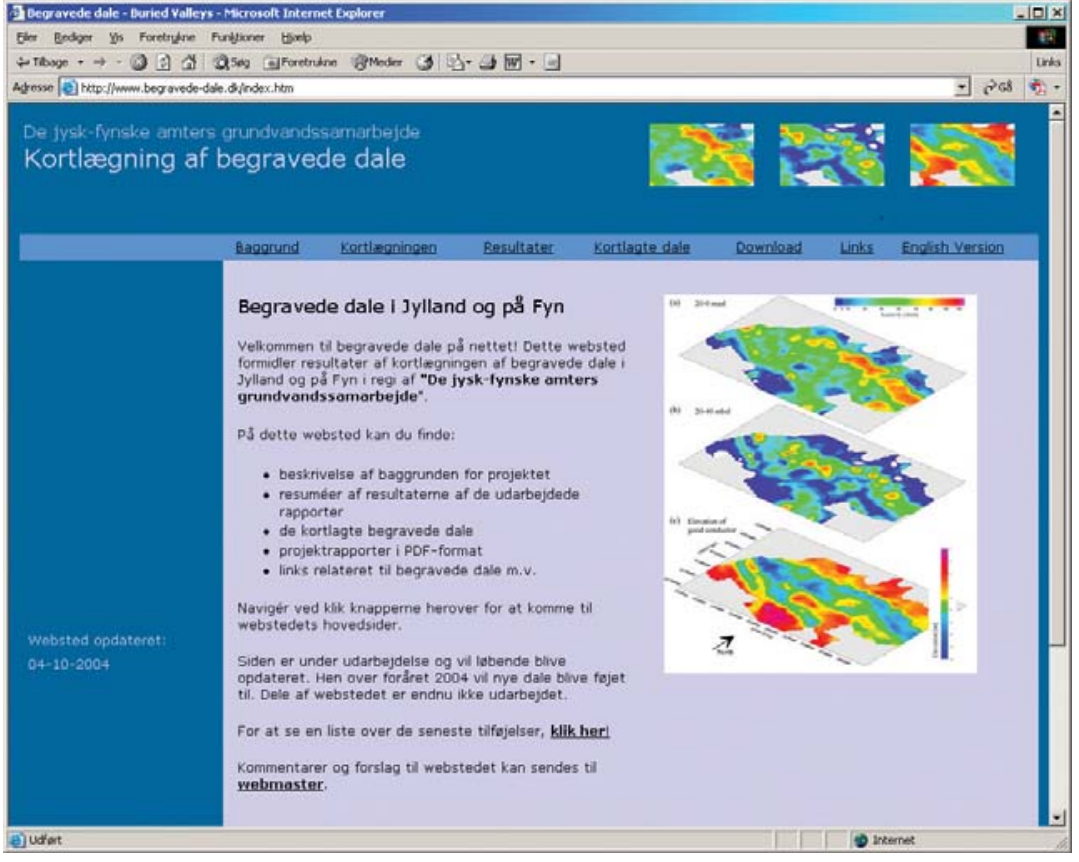

På www.begravede-dale.dk kan man bl.a. klikke ind på baggrund, kortlagning og resultater - hvis man ønsker at laese hele rapporter, der knytter sig til resultaterne, kan disse også downloades.

fokus på dalenes betydning i grundvandssammenhænge. Der er tilvejebragt et overblik over dalenes forekomst, og mange fælles karakteristiske træk ved dalene er blevet udpeget. Dertil kommer, at man er kommet tættere på en forståelse af, hvordan dalene er blevet dannet. Det betyder, at man nu på baggrund af billedet af de kortlagte dale kan forudsige en mulig tilstedeværelse af dale i områder, som endnu ikke er kortlagte. Herudover er der opbygget en stor viden om, hvilke målemetoder der kan anvendes til kortlægningen af dalene, og hvordan de målte data skal behandles og tolkes.

Resultaterne af kortloegningen af de begravede dale findes $i$ rapportform, og alle rapporter kan nu hentes fra websiden www.begravede-dale.dk. På denne webside er det også muligt ved få museklik at finde ud af, om der er kortlagt begravede dale $i$ et givent område. 